\title{
Elementary Teacher Education in the Top Performing European TIMSS Countries: A Comparative Study
}

\author{
Mohammed Sabrin ${ }^{1}$ \\ ${ }^{1}$ College of Education, Taibah University, AlMadinah AlMunawwarah, Kingdom of Saudi Arabia \\ Correspondence: Mohammed Sabrin, College Of Education, Taibah University, AlMadinah AlMunawwarah, \\ Kingdom of Saudi Arabia. Tel: 1-302-404-3850. E-mail: msabrin@taibahu.edu.sa
}

Received: November 18, 2017

Accepted: January 5, 2018

Online Published: March 28, 2018

doi:10.5539/ies.v11n4p152

URL: https://doi.org/10.5539/ies.v11n4p152

\begin{abstract}
This paper analyzed elementary teacher education (hereafter 'TED') programs in the top performing European (TIMSS) countries to help inform future elementary TED policy in the Kingdom of Saudi Arabia. Methodological emphasis revolved around how much emphasis should be placed on general content knowledge (GCK), as opposed to general pedagogical knowledge (GPK), as opposed to methodological pedagogical knowledge (MPK). This study explored these questions while analyzing the elementary TED programs of Germany, Finland, and the U.K. relying mainly on peer-reviewed literature on these topics published between 2000 and 2016 in the English language. Three theoretical frames of reference, aside from TIMSS, were also analyzed during this process: whether the programs were consecutive or concurrent, the model of partnership followed between universities and institutions where field experiences took place, and the overall status and role of teachers in the society as categorized by career-based or position-based. It was found that the top performing European TIMSS countries usually: have consecutive and concurrent options; attract the top academic achievers into their programs; have strict filters for admission; provide very intensive TED experiences to their students focusing on practical and diverse field experiences; enforce students to major in at least one academic subject and place more emphasis on academic subject expertise than pedagogy; have challenging criteria (including exams and portfolios) for graduation from the program; have national accreditation institutes for unifying standards; their sponsor countries enforce various types of induction and professional development once in the field; and lastly these countries offer salaries competitive with other professions that require the same amount of years and training since they are usually career-based positions.
\end{abstract}

Keywords: teacher education, TIMSS, Europe, comparative study

\section{Introduction}

This paper analyzes elementary teacher education programs in the top performing European (TIMSS) countries to help inform future TED policy in the Kingdom of Saudi Arabia. This is pivotal since there is still a very controversial and complicated understanding in the literature as to: how much emphasis should be placed on general content knowledge (GCK), as opposed to general pedagogical knowledge (GPK), as opposed to methodological pedagogical knowledge (MPK). This study explores these questions while analyzing the elementary TED programs of the countries: Germany, Finland, and the UK. It also relies mainly on peer-reviewed literature on these topics published between 2000 and 2016 in the English language regarding TED programs that prepare students to teach at the 'primary level' (a term that variously covers KG-8th grade or KG-5th depending on the context). We will now turn to three theoretical frames of reference, aside from TIMSS, that will be utilized throughout this study.

One could say that generally speaking there is a spectrum of initial teacher education models found globally (aside from the issue of undergraduate or graduate), ranging from the concurrent to the consecutive. The consecutive model is where students receive a bachelor's degree in a particular subject and then enroll in a Masters level program of TED at the end of their degree. The concurrent model is that which combines specialized education in one or more academic subjects with TED (coursework and field experiences) throughout the completion of the bachelor's degree. The OECD countries in particular could be categorized as belonging to one of these two categories or having both options within the same country, with the exception of Germany. In Germany, students study according to a concurrent model in the Bachelor's level portion of their TED; however, their Masters is also 
not just in pedagogical studies, but is also concurrent. The difference between the bachelor's and the Master's phase is that in the Masters phase, the focus is more on practical field experiences as full-time teachers - usually in public institutions, but sometimes at special institutions built for this purpose. Hence, Germany has a combination of the two categories; or if one decided to label this a unique application of the consecutive model, then Germany would be one of the few countries to only offer consecutive model TED programs (Ingvarson et al., 2013, p. 24, p. 50). 11 of 35 and 17 of 22 OECD countries with available data require a M.S. degree for primary level and secondary level teaching respectively (OECD, 2014, p. 502). These categories will be important indicators for describing the general framework of TED programs in this study,

The second theoretical reference point for this study will be the model of partnership followed between universities and the institutions where their field experiences take place (usually PDSs - professional development schools).

Some scholars (Buitink \& Wouda 2001 in Maandag, Deinum, Hofman, \& Buitink, 2007) have tried to synthesize the different types of collaboration between schools and universities into five models: school as workplace (work placement model); school with a central supervisor (coordinator model); trainer in the school as a trainer of professional teachers (partner model); trainer in the school as the leader of a training team in the school (network model); and training by the school (training school model). The main difference along this spectrum is that power and responsibility of the university gradually secedes to the school going from the first to the fifth model. This paradigm will be applied to TED field experiences in this study when enough data is available to classify.

The third theoretical reference point for this study will be the overall status and role of teachers in the society as categorized by career-based or position-based. Essentially, the former is more centralized with the teacher as a civil servant, compared to the latter being decentralized to local authorities. Career-based countries are the likes of South Korea, France, and Japan — where all decisions regarding recruitment, pay, area of placement, and the like, are through the ministry of education; salaries through such systems tend to be much higher over time based on experience compared to position-based systems. Position-based countries are those like the UK and U.S., where matters are decided at local, district, city, or statewide levels; salaries tend to flatten out much faster in such systems, but teachers are more free to work where they please and more autonomous in when and if they work, etc. Career-based systems put the burden of finance, but luxury of control with the government (particularly helpful when trying to avoid teacher shortages in fields unpopular with top achieving students like math and science). Teachers in such systems have the luxury of life long positions, but reduced freedom. Developing countries under pressure to spread educational access as fast as possible, with meager resources, tend to usually use a hybrid system hoping to fill as many positions as possible (Ingvarson, 2013, p. 112).

At the sake of oversimplification, we could say that career-based positions are more prominent in more politically and culturally centralized countries; whereas position-based positions are in more politically and culturally individualistic (decentralized) or 'market-based' countries. Given the geo-political influence of the U.K. on the world stage, this study will start with a discussion of their TED programs.

\section{UK}

\subsection{Context}

The UK has a very decentralized educational system when compared globally. The four countries that comprise the UK-England, Wales, Scotland, and North Ireland - each have their own legal and educational systems. Expectedly, teacher certification is not reciprocally accepted between the four countries of the UK. While the three Gaelic countries provide TED through a specific limited number of universities, England has a wide array of options; however, England and Wales do have one comprehensive school system (Macbeath, 2012, p. 66, p. 68).

In the 2011 TIMSS results, North Ireland ranked $6^{\text {th }}$, and England and Wales ranked $9^{\text {th }}$ for $4^{\text {th }}$ grade Math; England and Wales achieved $10^{\text {th }}$ place for $8^{\text {th }}$ grade math; in $4^{\text {th }}$ grade science none of the UK countries ranked in the top 10, and England and Wales ranked $9^{\text {th }}$ in $8^{\text {th }}$ grade science (TIMSS, 2016). Other than what has been mentioned, none of the other UK countries ranked in the top 10 of the TIMSS rankings.

Given the fact that England is undoubtedly the geopolitical center of the UK, this discussion will focus on the TED systems of England. The defining feature of the changes that have occurred in England over the last 30 years is the increased centralization of policy and standards, while providing autonomy to the various providers of TED in the country to reach these results as they please. Up until about 30 years ago, there was no national curriculum in England and teachers enjoyed a great amount of autonomy in how they taught compared to the rest of mainland Europe. However, in 1988 a national curriculum was established and implemented, after the establishment of a national curriculum for TED in 1984 by the Council for Accreditation of Teacher Education (CATE). CATE 
significantly reduced the amount of 'educational' subjects (i.e.: pedagogy, psychology, etc.). CATE was abolished in 1994 and replaced by the TTA (Teacher Training Agency), which focused TED as more centered on the academic disciplines in question (than education) and apprentice-based, as can be gleamed from their title. Since these changes, English TED has focused on centralized outcomes in TED policy instead of controlling the ways providers reach those outcomes (Ostinelli, 2009, p. 298). We will now turn to England--which allows the consecutive and concurrent models for primary TED and could be deemed a position-based country in regards to the teaching profession.

In England, there is a strong emphasis on content knowledge, more intensive field experiences, and the existence of induction programs. We will provide a summary of the main pathways to QTS (qualified teaching status) in England.

\subsection{English TED}

The first option is the Bachelor of Education (BEd). It usually lasts between three and four years, and four and six years, depending if one is full-time or part-time. It is primarily intended for teaching in primary schools, but also acceptable for secondary education. A Bachelor's of Arts (BA) or a Bachelor's of Sciences (BSc) with QTS is also a path to becoming a teacher. At the 'postgraduate' level there is the Postgraduate Certificate in Education (PGCE), which is geared mostly towards those desiring to teach at the secondary level and requires about one year full-time. There is also the SCITT (School-centered initial teacher training), which is offered by an array of schools and colleges, and allows students to complete their 'postgraduate' education in schools with experienced teachers. It also leads to QTS and sometimes PGCE, taking one year full-time to complete. Also at the 'postgraduate' level is a program entitled Teach First, which is managed by independent organizations and allows students with 'excellent' degrees to work for two years in high-level schools throughout England to obtain the QTS. Although these are the three main recourses to acquiring the QTS, there are numerous other programs that essentially allow professionals in the working world at any time to teach at English schools as non-qualified teachers for three months to two years to eventually acquire QTS, not to mention the special programs customized for non-EU teachers. Needless to say EU teachers can use the same QTS procedures as British ones when they enter the country (Ostinelli, 2009).

While no research was found comparing the results of the 'mainstream' pathways to QTS in England and the alternative ones designed more for professionals, it is instructive to note the American experience with such private institutions that have tended to launch an aggressive neo-liberalist attack on the entire profession of teacher education in the U.S. In sum, U.S. teachers certified through 'traditional' pre-service programs consistently produce stronger student achievement gains than uncertified teachers that come from 'alternative' programs like Teach for America. The latter also leave the profession three times as much as the former (Darling-Hammond, 2005; Darling-Hammond, 2012, p. 136). Unfortunately however, it seems that the extreme shortage of teachers in the U.S. and the UK is probably one of the main reasons that such teachers are recruited to fill the dearth.

Nonetheless, what there has been scholarly attention to is the type of partnerships English TED programs offer between universities and schools, the "management and quality assurance of initial teacher training partnerships", to the extent that TED is becoming almost school-based in England (CJEAP, 2004, p. 3). The increased emphasis on the role of field experiences in TED has been international in the last two decades (Note 1) (Wang, 2001 and Cope and Stephen, 2001 as cited in CJEAP, 2004). By law, 1/2 to 2/3 of English TED (18-32 weeks) is 'in the field' despite what type of the various TED options described above students choose, and students must acquire some practical experience in at least two schools (Maandag et al., 2007, p. 157).

As for England, then although they offer a wide variety of pathways into teaching, they tend towards the coordinator and partner models of school-university collaboration (Maandag, 2007). We will provide a breakdown of one collaboration model in England at the University of Nottingham which has been said to be "among the best in the UK" by external examiners (CJEAP, 2004, p. 16).

\subsection{An English Case Study}

The University of Nottingham PGCE utilizes a partnership committee made up of both school-based and university-based staff to organize roles and responsibilities for their field experiences. There are 132 partner schools and roughly 700 trained mentors across the six teaching subjects covered by the collaboration. There is also a trained coordinator with responsibility for administering all details of the PGCE arrangements. The coordinator is usually a senior member of the school staff and handles quality insurance of the entire program. Since the PGCE is a graduate level program, it pushes student teachers more rigorously in the aspects of professionalism and reflective practice through inquiry-based projects. University tutors are responsible for monitoring students' progress and conducting a minimum of four observation visits of each student throughout the year, leaving the vast majority of the apprenticeship process in the hands of the school mentors (CJEAP, 2004, pp. 


\section{3-5).}

The responsibilities of the mentors fall into four broad areas: planning an appropriate program; managing a student teacher's experience in school; facilitating professional learning; and assessing the student teacher's performance throughout the program (CJEAP, 2004, p. 5). Feedback and evaluation are continuous throughout the year from mentors, students, and even external agencies, using questionnaires, focus group evaluations, inspections, and surveys. Student teachers are also entitled to regular scheduled meetings with their mentors. The only negative aspect is that it seems there is high turnover among mentors, which could be a pattern among teachers in general in the UK, since less than twenty percent had mentored for five years or more during the study that was undertaken in the 2002/2003 school year. In sum, the prime strength of the University of Nottingham's field experience model was their emphasis on strong rapport between mentor and student teacher as part of a fruitful apprenticeship relationship (CJEAP, 2004).

\subsection{The Proverbial 'Take-Away'}

Hence, as will be seen in comparison to the other countries in this study the UK probably focuses the most on the importance of the quality of the apprenticeship relationship between student teacher and mentor. One last criticism that has been posited of UK TED is that it is too strict in how it demands conformity to standards compared to what has been labeled the "Nordic vision" of creating reflective teachers in Finland, Sweden, Italy, and Germany (Ostinelli, 2009, p. 304). However, it seems that although not enough research has been found to discuss how reflective British teachers are, there does seem to be a tremendous amount of flexibility within the British system for how teachers reach the standardized policies in place. The next country to be discussed will be one whose TED programs' probably main criticism in the current literature (Ostinelli, 2009, p. 304) is lack of the type of synchronized collaboration that has been reported about the British experience-Finland.

\section{Finland}

\subsection{Context}

In the most recent TIMSS rankings Finland ranked eight for $4^{\text {th }}$ and 8 th grade Math. As for Science, Finnish students achieved third and fifth place for $4^{\text {th }}$ and $8^{\text {th }}$ grade respectively (TIMSS, 2016). Finland's TED system is probably the most admired globally due to the sheer transformation it has caused in the academic ability of the country's students over the past 30 years; hence, it deserves the most of our attention. It can be categorized as following both the concurrent and consecutive models depending on which kind of teacher is in question.

Teacher education in Finland has its roots back to the 1860s where TED took place in teacher colleges; however, it was transferred to universities by 1971 . These early programs were predicated on the idea that class teachers would major either in the science of education or a subject matter; both culminated in a master's degree (which included research methodology classes and even a master's thesis). Hence, even from this era the idea of the teacher as researcher was the predominant one in Finnish TED. The approach was that since teachers were in the best position to research the issues needed for improving the quality of education at their schools, they should be the ones to research - through qualitative and quantitative research ranging from narrative to action research. Participating in their own professional development by researching the teaching and learning of themselves and colleagues clearly had profound results. These results were among the reasons that policymakers also allowed TED to decentralize more and more throughout the $80 \mathrm{~s}$ and $90 \mathrm{~s}$ as educators were trusted to play the key role in constant re-evaluation and reconstruction of their schools and universities (Uusiautti \& Maatta, 2013). In this sense, policymakers focused more on results, rather than the way educators reached those results, similar to the UK. We will now turn to the current status of Finnish TED.

At the level of policy, Finland probably is the only TED program in the world to have a TED policy that is entirely constructed by faculty (in this case) from all Finnish universities that offer TED. It is only since 2006 that Finland has had national 'recommendations' (literally since it's not a legally binding document) for how TED should run in the country; and in fact even this policy is so flexible that it is called a "light framework" in policy documents (Afdal, 2012, pgs. 175-176). This is of course a stark contrast to the U.S. model for example. This policy was constructed through a three year project called the "National-Level Coordination of Degree Program Development in Teacher Education in the Sciences of Education" (the VOKKE project), and initiated and funded by the Ministry of Education. The head of the steering group (which even included student organizations) for this initiative was the Vice Rector of the University of Helsinki, whose university we will look at when discussing an example from the Finnish TED system. Even after all this, each university is still free to create its curriculum at its discretion since there are also no national standards (Niemi, 2011, p. 45) or national examinations except the Matriculation Examination. These national recommendations were published in 2006 entitled "Research-based teacher education in Finland-Reflections by Finnish Educators", which was edited by Ritva Jakku-Sihvonen and 
Hannele Niemi (two professors, the latter of which is also at the University of Helsinki) (Afdal, 2012).

\subsection{Finnish TED}

Finland has five categories of teachers: kindergarten; primary school; Subject; special education; and vocational. Kindergarten teachers teach in KG classrooms, and are also licensed to teach pre-school (Preschool education starts at the age of six in Finland and is voluntary and free) (Happo, Maatta, \& Uusiautti, 2012). Primary school teachers teach grades one to six; they normally teach one grade, but several subjects. Subject teachers teach one to three subjects either in the 'basic' mandatory grade levels of schools (which are $1-9^{\text {th }}$ grade) or the general upper secondary schools that come after this; they can also teach vocational schools. Special education teachers teach the relevant student body in primary schools or upper grades of basic school. Vocational education teachers teach in upper secondary vocational schools; they must have at least three years of work experience in their own teaching field before they can enter a vocational teacher preparation program. We will focus on primary and subject teachers since they fall under the definition of 'primary' in this study and are about 2/3 of all TED students in Finland (Sahlberg, 2012, pp. 3-4).

Teaching is a highly prized profession in Finland. Only one in ten primary TED applications are accepted for training (Darling-Hammond and Lieberman, 2012, p. 157). The selection of primary school TED candidates has two phases; in the first phase students take a national entrance exam revolving around education-related articles; then depending on exam scores, upper secondary school diplomas, and other extracurricular considerations, some are invited for interviews to assess their understanding of curricular issues and personality. It should be noted that even the typical upper secondary graduate in Finland is not very typical; students are required to complete 17 required subjects including physics, chemistry, philosophy, and at least two foreign languages - a feat that would seem semi-alien in the UK. Students accepted to primary school TED programs in Finland have achieved higher than average grades in these subjects (Sahlberg, 2012, p. 5, pp. 8-11).

The Finnish TED program is a two level degree program - roughly three years for a bachelor's degree and two years for a master's degree (Niemi, 2011, p. 44). The amount of credit hours is based on the Bologna concept of ECTS (European Credit Transfer and Accumulation System), which envisions one ECTS credit representing about 25-30 working hours, and 60 credits equaling a typical academic year in European tertiary education. The Bachelor's degree is 180 ECTS credits, and the Master's degree is 120 ECTS credits. Further reference to 'credits' in Finland will be according to this system. Students need a Master's degree to teach as a primary (the equivalent of what is often called elementary in the U.S.) or subject level teacher (which can teach from $1^{\text {st }}$ to $12^{\text {th }}$ grade), but nothing else in terms of certifications or accreditations from outside their universities. Both types of teachers take academic coursework simultaneously with their field experiences; the main difference is that primary teachers' curriculum is centered more on courses in educational disciplines (i.e.: teaching theories, subject methods courses, educational psychology, etc.), while subject teachers' curriculum is more focused on advanced knowledge of the subjects they specialize in. However, this does not mean that subject level teachers don't take pedagogical courses (Niemi, 2011, p. 45; Sahlberg, 2012, pgs. 5, 8-11).

\subsection{A Finnish Case Study}

For example at the University of Helsinki as of 2011, subject teachers at the Bachelor's level during their first year took pedagogical courses like: developmental psychology and learning (4 credits); special education (4 credits); introduction to subject didactics (10 credits); and basic teaching practice in Teacher Training School ( 7 credits). At the Master's level, students took courses like: Social, historical and philosophical foundations of education (5 credits); Evaluation and development of teaching (7 credits); Advanced teaching practice in Teacher Training School or Field school (5 credits); Research seminar (Teacher as a researcher) (4 credits); and Final teaching practice in Teacher Training School or Field School (8 credits) (see Appendix A from Sahlberg, 2012, p. 11).

An overall breakdown of the pedagogical studies courses for $3^{\text {rd }}$ year subject teachers is: introductory studies to teaching ( 2 credits); philosophical and historical bases of teaching and learning ( 9 credits); theoretical and practical bases of subject didactics ( 15 credits); research methodology and research on subject didactics ( 7 credits); and the social basis of education (2 credits), totaling 35 credits (Appendix B from Ostinelli, 2009, p. 303). Hence, pedagogical courses are not just for primary level teachers in Finland, particularly subject specific ones, aside from the fact that field experiences count towards their overall credit objectives.

\subsection{A Bird's Eye View of Finnish TED}

An important point about the Finnish TED framework is that primary level students essentially do a bachelor's degree in Education, then a Master's in education. However, subject teachers can do a Bachelor's degree in the subject of specialization, then do one year with all their pedagogical studies taken separately; or they can take their 
subject and pedagogical studies concurrently throughout their Bachelor's and Master's degrees. Also, Even though a primary level and subject teachers' majors are educational studies and various subjects respectively, they are still required to minor in the other aspect that they're not majoring in (i.e.: a primary level teacher would have to minor in a combination of the basics of different school subjects and specialize in one or two of them and vice versa for a subject teacher (Appendix B from Ostinelli, 2009, p. 302; Sahlberg, 2012, p. 11). Recently, the top U.S. TED programs have also started requiring students to specialize in a subject as their major, and have a minor or credential in education, during their four year concurrent programs; a forthcoming article (Sabrin, in press) will explore whether the U.S. is adopting any of the TED practices that seem to be achieving such high results on TIMSS in other countries. This is pertinent as Saudi Arabia is currently undergoing many educational transformations based upon the U.S. model of TED. Nonetheless, as for Finland, the interdisciplinary nature of Finnish TED can be seen at the University of Oulu for example where three of the six main faculties participate in the TED program: Science; Humanities; and Education, excluding only the faculties of Technology, Economics, and Medicine (Sahlberg, 2012, p. 12).

2/3 of field experiences as part of Finnish TED primarily take place at special Teacher Training Schools governed by universities, which are similar to regular public schools - although some experiences take place among the students themselves in seminars. The other $1 / 3$ of field experiences take place in regular public schools, but potential mentors must prove their competency to work with student teachers For primary school teachers, the percentage of time of the TED program in the field is about $15 \%$ (roughly 40 credits), and for subject level teachers it is about 33\% (Sahlberg, 2012, pp. 12-13).

As for what might be called induction, in-service, or professional development, this is the area where Finnish TED is somewhat more haphazard as it is not as systematic or uniform as the rest of the system and highly differs from area to area. For example, in 2007 1/3 of the Finnish teacher population did not participate in any professional development that year (Kumpulainen in Sahlberg, 2012, p. 14). While one can admit that this is an opportunity for improvement in Finnish TED, one must also admit that the typical graduate is probably far more prepared for the field than the average teacher globally.

\subsection{The Proverbial 'Take-Away'}

At the end of the aforementioned, Finnish teachers are not only reflective practitioners, but professionals to the extent that they only need be at the school when they have classes to teach or other duties, which may be why the typical middle school teacher in Finland teaches on average 600 hours annually, about four 45 minute lessons daily (400 hours less than the OECD average of 1000 hours) (OECD in Sahlberg, 2012, p. 17). It seems acknowledged in the Finnish system that quality education requires numerous duties outside of the classroom, from helping students to lesson planning. We will now turn our attention to Germany.

\section{Germany}

\subsection{Context}

Germany is the last country for this study, but has not reached the top ten in TIMSS since the 1990S; there also has been very limited research found given the parameters of this study. Hence, the discussion of its TED will be noticeably more concise. Germany could be said to have a consecutive system for primary and secondary teachers; however, during both the B.A. and M.S. portions of their program the curriculum is concurrent (academic subjects and 'educational' courses). Hence, in actuality it is the only country in Europe to have what would better be classified as a hybrid system (Ingvarson, 2013, p. 24).

Germany is divided into 16 'lands' (the rough equivalent of a U.S. state), and each land is responsible for its own TED within the parameters of the national framework. One land's academic degrees are not necessarily accepted in others. We'll provide a sketch of the educational system before delving deeper.

\subsection{German TED}

The Grundschule (primary school) - is grades 1-4 in 14/16 federal states, and grades 1-6 in the other two states. As for what could be called secondary school, there are four very different options. The first is the Hauptschule - the least academic and most practical type of lower secondary education, after which students either work and attend vocational training (part-time) simultaneously, or attend the latter full-time. The second option is the Realschule - a more selective version of secondary for grades 5-10, 27 percent of eighth graders attend this form. These schools are typical for lower white-collar positions and technical occupations. The third option is the Gymnasium; this is an elite form of secondary - 33 percent of eight graders preparing for the Abitur (the university entrance exam) are at these schools. The last option is the Gesamtschule - this is a comprehensive school with various programs from other schools; this has only about 9 percent of eight graders enrolled in recent statistics 
(Ingvarson, 2013, p. 50).

There are five types of TED programs generally speaking. The first type is for teachers of grades one to four without math as a teaching subject (type $1 \mathrm{~b}$ ). This program is essentially 3.5 years for the bachelor's portion, and two years for the Master's portion of the TED program. Future teachers in Germany must finish a Master's to teach. Such teachers are classified as Generalists. The second type of TED program is type 2A. A teacher becomes a specialist in two subjects licensed to teach grades 1-10 with math as a teaching subject. The duration of the program in total is 5.5 years and the teacher must take the primary and secondary exams to graduate. The third type of TED program in Germany is the type $2 \mathrm{~b}$, which is also 5.5 years total, licensed to teach grades 1-10 without math as a subject, is a generalist, and takes only the primary examination to graduate. The fourth type of TED program in Germany is the type 3, which is 5.5 years total, licensed to teach grades 5-10 with math as a subject, is a specialist in two subjects, and takes only the secondary examination to graduate. The fifth type of TED program is the type 4, which is 6.5 years long; graduates are certified to teach grades 5-13 with math as a subject, specialize in two subjects, and only take the secondary examination to graduate. There are 74 universities providing TED at the moment (Ingvarson, 2013, p. 26, p. 50).

After graduation with the Abitur ('school leaving certificate'), future teachers enroll in a university where they can choose between two disciplines (for secondary school), or three disciplines (for primary school), aside from their education courses (i.e.: pedagogy, psychology, etc.). They study for seven and nine semesters for primary and secondary school 'certification' respectively; two to three years of this time is apprenticeship experience. At the end of this first phase of the TED program they take their state examinations; this exam consists of several written and oral examinations related to the subjects' studies, and a long essay. This first phase is about 42 months for primary and 54 months for secondary future teachers including breaks and vacations (since students also get assignments during breaks). Germany is also one of the rare countries among the OECD countries, but not rare among the top five TIMSS countries for example like Singapore, to enforce even primary teachers to specialize in academic subjects like math and science (Ingvarson, 2013, p. 31, p. 51; Ostinelli, 2009, pp. 295-296).

The second phase of German TED is in institutions outside the university (guided by experienced teachers) where student teachers teach independently and are even paid. These institutions are called Studienseminare and this phase lasts 18-24 months. Aside from the field experiences, students continue to take regular coursework in subject-specific pedagogy and general pedagogy organized by their Studienseminar (Ingvarson, 2013, pp. 50-51; Maandag et al., 2007, p. 156; Ostinelli, 2009, pp. 295-296).

Lastly, students take a second state exam (more practical than the first), which consists of teaching and being assessed by a board of examiners, an essay, and sometimes oral exams (Ingvarson, 2013, p. 51). At this point students are eligible for teaching positions according to their exam scores. After three years of professional practice, teachers are evaluated once again and appointed pending their evaluation results. The main criticism of the German TED system is that there is no organized relationship between the disciplinary courses and educational courses, fieldwork, and later workshops at the 'Centers of teacher education', which particularly affects any benefit to later in-service education of any sort; also, the exams are seen to merely reward short term memory. Such coordination is important because fieldwork for example is about 2/3 of the TED program (Maandag et al., 2007, p. 156; Ostinelli, 2009, pp. 295-296). Germany has the highest reported days of obligatory teaching practicum in OECD countries with available data at 282+ days (OECD, 2014, p. 502). However, lack of coordination between these various components has been reported as a key criticism in other studies relating to not only Germany, but Turkey, and Denmark as well (Yelken, 2009). German TED's collaboration model would be closest to the work placement model in the spectrum discussed above (Maandag, 2007, p. 157).

Nonetheless Germany is one of the few places where empirical evidence has been found on the importance of education courses in acquiring 'professional vision', essentially conceptual knowledge that allows teachers to analyze classroom situations, predict their outcomes and effects, and consequently how to react-particularly courses that utilize case-based learning, self-reflection exercises, and videos of classroom teaching (Sturmer, Konings, \& Seidel, 2013). Their career-ladder is also based on merit and not mere seniority, something worthy of imitation. Also, schools are starting to have a much bigger say in choosing who gets appointed to their schools, to the extent that one could say that the states of former East Germany could be considered position-based careers and not career-based (Ingvarson, 2013, p. 93, p. 118). We'll finish with one case study of the curriculum breakdown of a German TED program.

\subsection{A Case Study}

At the University of Berlin (Teacher Training, 2016), the first part of TED is a three-year combined bachelor's degree. At the end of this, students are awarded the Bachelor of Arts or Bachelor of Science degree. A two-year 
teacher training focused master's degree follows this. The Master of Education enables candidates to apply for induction service as trainee teachers (in German: Referendariat). The induction service ends with a state examination. Upon passing this final examination teachers can teach at public or private schools. Here is the breakdown of the coursework.

Credit points (CP) are awarded in compliance with the European Credit Transfer System (ECTS). One credit point (LP) equals a workload of 25 to maximum of 30 hours for preparation and review as well as for attending classes. Students take $42 \mathrm{LP}$ in each subject (three subjects required), and then specialize in one for an extra $10 \mathrm{LP}$. Then there's a complementary course of 10 LP, 8 LP for pedagogy, and 16 LP for special education topics. The thesis is $10 \mathrm{LP}$, which totals 180 for the Bachelor's program (unless the student gets the extra certification for special education which requires additional coursework). The resulting Teaching certificate is for grades 1-6. The bachelor's program is called "education in primary schools", the subsequent Master's program is called "teaching at primary schools".

The Master's program is 120 LP. The same subjects specialized in during the bachelor's must be the same ones continued for the Master's. No information was found on the breakdown of the credit hours for it.

\section{Conclusion}

\subsection{A Comparative Look}

Coming full circle, we have seen that the UK is probably the second strongest in teacher education, as measured by TIMSS, among the four European territories analyzed. It comes after Finland in ranking generally speaking. We saw that it is similar to Germany geopolitically given its division into different systems for each country, as Germany does with each of its 16 'lands'. Despite its diverse nature, the common denominator in the U.K. is that at least in the case of England and Wales results are achieved. Unfortunately, it seems that North Ireland and Scotland have yet to join the rest of the U.K.'s success. England's teachers are position-based, and their university-school collaboration was somewhere between a coordinator/partner model on the Buitink and Wouda scale. We have also seen that as England transitioned from the Council for Accreditation of Teacher Education to the Teacher Training Agency, emphasis became more focused on increasing aptitude in academic content knowledge and strengthening the apprenticeship approach of TED. This trend led to better results on standardized examinations such as TIMSS over the years. It was also seen that the unifying focus of English TED was on the field experience and that this was even enforced by law, despite the overall trend for other aspects of English TED to be a sundry conglomerate of approaches. We even saw how despite the fact that Finland performs better than the U.K. in TIMSS, a clear highlight of the latter's TED that the former could benefit from is the synchronized collaboration between what occurs in the classroom with what occurs in field experiences. Nonetheless, one area of research we are not yet sure of is the extent of reflectivity among U.K. teachers, and this is one of the main areas of strength with Finnish TED: the production of reflective researchers as teachers.

Similar to the U.K., Finland was also found to practice a decentralized form of TED, focusing merely on uniform results and not pathways to get them. Similar to the U.K., Finland also offers concurrent as well as consecutive options for reaching teacher accreditation. One area where Finland touts a profound idiosyncrasy however, compared to our other European states in question is its extremely interdisciplinary coursework as has been described. The main weaknesses of Finnish TED nonetheless, have been found to be the lack of synchronization between professional development (field experiences) and the in-class university coursework, as well as non-uniform induction practices that differ from area to area. Finland's field experiences are mostly at university based, and not regular public, schools, and teachers participate in a career-based position.

Lastly, Germany was found to be the weakest of our competitors in the nature of its TED programs, and more importantly its outcomes. Similar to the U.K.'s geopolitical situation, Germany is divided into 16 'lands', where each land's certification is usually not accepted in others. A clear highlight of Germany's TED programs was found to be its unique utilization of a 'hybrid' consecutive and concurrent TED design. Similar to Finland in length, Germany requires 5.5-6.5 years of study post 'high-school', even for primary teachers. This is different from the more lax system in England, particularly for the primary level. Finland and Germany also emphasize academic content knowledge and pedagogical knowledge over general pedagogical knowledge, and are much more interdisciplinary and rigorous than England. Furthermore, Germany also breeds reflective teachers with a professional 'vision' similar to Finland's focus, albeit somewhat less in rigor. Germany's main criticism was similar to Finland in lack of pedagogical coordination between in-class academic work and field experiences; however, induction practices seemed to be well established. East Germany inclined towards a position based framework for teachers, and West Germany towards a more career-based one. 


\subsection{The Proverbial 'Take-Away'}

We can say after looking at the TED systems of the aforementioned countries that it seems the top performing European TIMSS countries usually have the following in common in their TED programs: they attract the top academic achievers into their programs; they have strict filters for admission even aside from general academic achievement; they provide very intensive TED experiences to their students focusing on practical and diverse field experiences that allow hands-on application of knowledge learned in coursework simultaneously; they enforce students to major in at least one academic subject and place more emphasis on academic subject expertise than pedagogy; they have challenging criteria (including exams and portfolios) for graduation from the program; there are national accreditation institutes for unifying standards; their sponsor countries enforce various types of induction and professional development once in the field; and lastly these countries offer salaries competitive with other professions that require the same amount of years and training such as engineering and medicine.

On this last point, a recent study regarding the top performing countries on PISA, it was found that the top European countries recruit their future teachers from the top third of each cohort: top 10 percent in Finland; and the top 30 percent in Germany (Ingvarson, 2013, p. 156, p. 169). Such countries can probably afford to do so since their centralized career-based system, unlike lower performing countries such as the U.S., only allow into (and pay for) teacher training the amount and type of students who will almost indefinitely be career teachers. Since Saudi Arabia's educational system is also career-based, it seems higher selection criteria could also be encouraged in Saudi Arabia and be worth the investment to attract and keep the most qualified teacher candidates. Nonetheless, since Saudi Arabia has also just initiated 'Vision 2030', a sort of privatization schema for the entire economy, Finland's vision of teachers as reflective researchers, could also become more and more appropriate as this program develops.

While it is quite easy to become complicit in intellectual colonization through the copy and paste of intellectual structures utilized in global imperial powers' TED programs (Kerr, 2014; Sabrin, 2013), it seems the aforementioned ideas, if adopted in a culturally relevant fashion, would be of tremendous benefit to the Kingdom of Saudi Arabia. In conclusion, it seems, as Goodwin (2012 in Darling-Hammond, 2012) and Ingvarson, Meiers, and Beavis (2005 in WKP 2010) have argued, that the overall structures of TED programs by themselves (consecutive vs. concurrent, etc.) are not as important as some of the more micro level issues raised in this conclusion. This study particularly highlighted the importance of the rigor and quality of coursework, the nature of field experiences, and the role of the teacher in society. Directions for further research should also include a data set equivalent to that of TEDS-M for science, as no doubt math and science are the two legs of any successful TED system in the modern age. Also, it seems that since some Asian countries are performing noticeably better on TIMSS than European ones, an exploration of their TED systems is pertinent.

\section{References}

Afdal, H. W. (2012). Policy making processes with respect to teacher education in Finland and Norway. Higher Education, 65, 167-180.

Canadian Journal of Educational Administration and Policy (CJEAP). (2004). The impact of quality assurance on mentor training in initial teacher education partnerships: A UK perspective. Canadian Journal of Educational Administration and Policy, 32.

Darling-Hammond, L. (2012). Teacher preparation and development in the United States: A changing policy landscape. In L. Darling-Hammond, \& A. Lieberman (Eds.), Teacher education around the world: Changing policies and practices (pp. 130-150). New York: Routledge.

Darling-Hammond, L., \& Lieberman, A. (2012). Teacher education around the world: What can we learn from international practice. In L. Darling-Hammond, \& A. Lieberman (Eds.), Teacher education around the world: Changing policies and practices (pp. 151-169). New York: Routledge.

Darling-Hammond, L., Holtzman, D. J., Gatlin, S. J., \& Heilig, J. V. (2005). Does teacher preparation matter? Evidence about teacher certification, teach for America, and teacher effectiveness. Education Policy Analysis Archives, 13(42). https://doi.org/10.14507/epaa.v13n42.2005

Goodwin, L. (2012). Quality teachers: Singapore style. In L. Darling-Hammond, \& A. Lieberman (Eds.), Teacher education around the world: Changing policies and practices (pp. 22-43). New York: Routledge.

Happo, I., Maatta, K., \& Uusiautti, S. (2012). How do early childhood education teachers perceive their expertise? A qualitative study of child care providers in Lapland, Finland. Early Childhood Education, 41, 273-281.

Ingvarson, L., Schwille, J., Tatto, M.T., Rowley, G., Peck, R., \& Senk, S.L. (2013). An analysis of teacher 
education context, structure, and quality-assurance arrangements in TEDS-M countries: Findings from the IEA teacher education and development study in mathematics (TEDS-M). Retrieved from http://www.iea.nl/fileadmin/user_upload/Publications/Electronic_versions/TEDS-M_Findings.pdf

Kerr, J. (2014). Western epistemic dominance and colonial structures: Considerations for thought and practice in programs of teacher education. Decolonization: Indigeneity, Education \& Society, 3(2), 83-104.

Maandag, D. W., Deinum, F. F., Hofman, W. H. A., \& Buitink, J. (2007). Teacher education in schools: an international comparison. European Journal of Teacher Education, 30(2), 151-173. https://doi.org/10.1080/02619760701275552

Macbeath, J. (2012). Teacher training, education or learning by doing in the UK. In L. Darling-Hammond, \& A. Lieberman (Eds.), Teacher education around the world: Changing policies and practices (pp. 66-80). New York: Routledge.

Niemi, H. (2011). Educating student teachers to become high quality professionals - a Finnish case. CEPS Journal, 1(1).

OECD. (2014). Indicator D6: What does it take to become a teacher? In Education at a Glance 2014: OECD Indicators, OECD Publishing.

Ostinelli, G. (2009). Teacher education in Italy, Germany, England, Sweden and Finland. European Journal of Education, 44(2). https://doi.org/10.1111/j.1465-3435.2009.01383.x

Sabrin, M. (2013). Exploring the Intellectual Foundations of Egyptian National Education (Doctoral dissertation, The University of Georgia).

Sabrin, M. (2018) (forthcoming). Weighing the costs and benefits of attending the top three U.S. elementary teacher education programs: A comparative look at educational practices. International Journal for Educational Studies.

Sahlberg, P. (2012). The most wanted: Teachers and teacher education in Finland. In L. Darling-Hammond, \& A. Lieberman (Eds.), Teacher education around the world: Changing policies and practices (pp. 1-21). New York: Routledge.

Sturmer, K., Konings, K. D., \& Seidel, T. (2013). Declarative knowledge and professional vision in teacher education: Effect of courses in teaching and learning. British Journal of Educational Psychology, 83, 467-483. https://doi.org/10.1111/j.2044-8279.2012.02075.x

$\begin{array}{llll}\text { Teacher } & \text { Training. } & \text { (2016). } & \text { Retrieved }\end{array}$ https://www.hu-berlin.de/en/institutions/scientific-institutions/central-institutes/pse/teacher-training

TIMSS. (2016). Retrieved from http://timssandpirls.bc.edu/

Uusiautti, S., \& Maatta, K. (2013). Significant trends in the development of Finnish Teacher Education programs (1860-2010). Education Policy analysis Archives, 21(59). https://doi.org/10.14507/epaa.v21n59.2013

Yelken, T., (2009). An evaluation of the teacher development program standards by European teacher candidates from Turkey, Germany, and Denmark. Education Sciences: Theory and Practice.

\section{Note}

Note 1. However, this is not without its costs; paying schools for their contributions to field experiences when a program is primarily field experiences such as the UK can be catastrophically expensive. This is aside from the fact that recent research shows that the key is developing a balanced between autonomy and support in field experiences, and not just the mere quantity (Konig \& Blomeke, 2014). 


\section{Appendix A}

Table 1.3 Structure of the pedagogical component of the subject teacher educacion program at the University of Helsinki in 2011

\begin{tabular}{|c|c|}
\hline Aocheior's level (2S ECTS credits) & Master's level (35 credits) \\
\hline $\begin{array}{l}\text { First Term (18 credits) } \\
\text { - Devolopmental psychology } \\
\text { and learning (4) } \\
\text { - Special education (4) } \\
\text { - Introduction to subject } \\
\text { didactics (10) }\end{array}$ & $\begin{array}{l}\text { Third Term (17 credits) } \\
\text { 1. Social, historical and philosophical } \\
\text { foundations of education (S) } \\
\text { - Evaluacion and development of } \\
\text { teaching (7) } \\
\text { - Advanced coaching practice in Teacher } \\
\text { Training School or Ficld School (S) }\end{array}$ \\
\hline $\begin{array}{l}\text { Second Term (7 credits) } \\
\text { - Basic teaching practice in } \\
\text { Teacher Training School (7) }\end{array}$ & \multirow{2}{*}{$\begin{array}{l}\text { Fourch Term (12 credics) } \\
\text { - Research seminar (Teacher as a } \\
\text { researcher) (4) } \\
\text { - Final teaching practice in Teacher } \\
\text { Training School or Field School (d) }\end{array}$} \\
\hline $\begin{array}{l}\text { As part of Master's program: } \\
\text { - Rescarch methodology }(6)\end{array}$ & \\
\hline
\end{tabular}

\section{Appendix B}

TABI.E II. The main components of teacher education in Finland

\begin{tabular}{|c|c|c|c|c|c|}
\hline & Major & Minor & $\begin{array}{l}\text { Master } \\
\text { Thesis }\end{array}$ & $\begin{array}{l}\text { Teaching } \\
\text { practice }\end{array}$ & $\begin{array}{l}\text { Other } \\
\text { studies }\end{array}$ \\
\hline $\begin{array}{l}\text { Primary } \\
\text { school } \\
160 \text { credits } \\
\text { (4-5 years) }\end{array}$ & $\begin{array}{l}\text { Educational } \\
\text { studies } \\
\text { in the } \\
\text { Education } \\
\text { faculties } \\
55 \text { credits }\end{array}$ & $\begin{array}{l}\text { Combination of } \\
\text { bassics of different } \\
\text { school subjects } \\
\text { and specialisation } \\
\text { in one or two of } \\
\text { them } 35+35 \\
\text { credits }\end{array}$ & $\begin{array}{l}\text { In education } \\
20 \text { credits }\end{array}$ & $\begin{array}{l}\text { As part of the } \\
\text { educational } \\
\text { studies } \\
\text { (20 credits) }\end{array}$ & $\begin{array}{l}\text { Lenguage and } \\
\text { communication } \\
\text { Optional courses } \\
10-20 \text { credits }\end{array}$ \\
\hline $\begin{array}{l}\text { Secondary } \\
\text { shool } \\
160 \text { credits } \\
\text { (5 years) }\end{array}$ & $\begin{array}{l}\text { Different school } \\
\text { subjects in } \\
\text { academic } \\
\text { faculties } \\
55-60 \text { credits }\end{array}$ & $\begin{array}{l}\text { One or two other } \\
\text { subjects } \\
\text { Education in the } \\
\text { Education Faculty } \\
30+35 \text { credits }\end{array}$ & $\begin{array}{l}\text { In academic } \\
\text { subjects } \\
20 \text { credits }\end{array}$ & $\begin{array}{l}\text { As part of the } \\
\text { educational } \\
\text { studies } \\
\text { ( } 20 \text { credits) }\end{array}$ & $\begin{array}{l}\text { Language and } \\
\text { communication } \\
\text { Optional courses } \\
10-20 \text { credits }\end{array}$ \\
\hline
\end{tabular}

\section{Copyrights}

Copyright for this article is retained by the author(s), with first publication rights granted to the journal.

This is an open-access article distributed under the terms and conditions of the Creative Commons Attribution license (http://creativecommons.org/licenses/by/4.0/). 